\title{
Cytotaxonomy, morphology and molecular systematics of the Bioko form of Simulium yahense (Diptera: Simuliidae)
}

\author{
R.J. Post ${ }^{1 *}$, P.K. Flook ${ }^{2}$, A.L. Millest ${ }^{3}$, R.A. Cheke ${ }^{4}$, \\ P.J. McCall ${ }^{2}$, M.D. Wilson ${ }^{5}$, M. Mustapha ${ }^{1}$, S. Somiari ${ }^{6}$, \\ J.B. Davies ${ }^{2}$, R.A. Mank ${ }^{7}$, P. Geenen ${ }^{7}$, P. Enyong8 ${ }^{8}$, A. Sima ${ }^{9}$ \\ and J. Mas ${ }^{10}$ \\ ${ }^{1}$ Department of Entomology, The Natural History Museum, Cromwell \\ Road, London, SW7 5BD, UK: ${ }^{2}$ Division of Parasite and Vector Biology, \\ Liverpool School of Tropical Medicine, UK: ${ }^{3}$ Department of Biological \\ Sciences, University of Salford, UK: ${ }^{4}$ Natural Resources Institute, \\ University of Greenwich, Chatham, UK: ${ }^{5}$ Noguchi Memorial Institute for \\ Medical Research, University of Ghana, Ghana: ${ }^{6}$ Windber Research \\ Institute, Windber, USA: ${ }^{7}$ Animal Taxonomy Section, Wageningen \\ University, The Netherlands: ${ }^{8}$ Medical Research Station, Kumba, \\ Cameroon: ${ }^{9}$ Onchocerciasis Control Programme, Ministry of Health, \\ Malabo, Equatorial Guinea: ${ }^{10}$ Onchocerciasis Control Programme, Spanish \\ International Cooperation Agency, Malabo, Equatorial Guinea
}

\begin{abstract}
Cytotaxonomic analysis of the polytene chromosomes from larvae of the Simulium damnosum Theobald complex from the island of Bioko in Equatorial Guinea is reported, and a new endemic cytoform is described. Chromosomally this cytoform is close to both S. squamosum (Enderlein) and S. yahense Vajime \& Dunbar, but is not identical to either. However, it is morphologically and enzymatically identical to $S$. yahense. The Bioko form was also found to differ from other cytoforms of the S. damnosum complex in West Africa in the copy number or RFLP pattern of several different repetitive DNA sequences. It is clear that the Bioko form is genetically distinct from other populations of the $S$. damnosum complex, and whilst it is closest to $S$. yahense, it shows features that suggest a high degree of geographical and genetic isolation. Such isolation is an important consideration in the assessment of the potential for onchocerciasis vector eradication on Bioko.
\end{abstract}

\section{Introduction}

Human onchocerciasis is a severely debilitating and blinding disease caused by infection with the parasitic nematode Onchocerca volvulus (Leuckart) (Nematoda:

${ }^{*}$ Fax: +44 (0)20 79425229

E-mail: R.Post@nhm.ac.uk
Filarioidea). In West Africa onchocerciasis is transmitted exclusively by sibling species of the Simulium damnosum Theobald complex (Diptera: Simuliidae), with blindness rates reaching as high as $15 \%$ in the savanna with up to $100 \%$ of adults infected. Infection rates can be similarly high in the forest bioclimatic zone, and although the ocular manifestation is usually very much less than in the savanna (with blindness rates typically around 0.5\%, see Duke, 1990) 
onchocercal skin disease can be a significant socio-economic problem (Remme, 1995). The major patterns of epidemiological variation are correlates of the taxonomy of both the parasite and the vector (Post \& Boakye, 1992), and so not all sibling species are equally important.

The island of Bioko (formally Fernando Po) is part of the Republic of Equatorial Guinea, and is situated $40 \mathrm{~km}$ off the coast of Cameroon. An epidemiological survey of the disease on Bioko (Mas et al., 1990, 1995) found an overall prevalence of $75 \%$ with a mean microfilarial density of 32 per skin biopsy. Blindness, due to all causes was registered at $0.8 \%$, which is similar to that seen in the forest endemic areas of West Africa and Cameroon (WHO, 1987), and 29\% of the total population had onchocercal skin disease. Thus onchocerciasis was shown to be hyperendemic and the whole population of 62,000 was estimated to be at risk. There have been almost no systematic studies of the biology of the vector and the level of transmission on the island, but S. damnosum s.l. is known to breed in the numerous small (sometimes seasonal) streams (Calvo Picó, 1962; McCall et al., 1998). It seems to be chromosomally distinctive (Post et al., 1995), but is morphologically similar to S. yahense Vajime \& Dunbar (Simuliidae) (Wilson et al., 1994) and is undoubtedly the vector (Cheke et al., 1997). Duke et al. (1966) included flies from Bioko in their classic study which defined the existence of separate forest and savanna Onchocerca-Simulium complexes, and concluded that Bioko fell into the forest group. Furthermore Lewis \& Duke (1966) described a sample of 20 flies as being 'dark' and belonging to the forest group. McCall et al. (1997) used some flies from Bioko in their analysis of oviposition aggregation pheromone and concluded that the composition of the pheromone was similar throughout the $S$. damnosum complex.

Until recently, onchocerciasis control in West Africa was effected solely by vector control because no suitable drugs were available for community treatment. The prospects for vector control over the whole island of Bioko are at first sight not good, because of the very large number of streams in which S. damnosum s.l. breeds. However, actual eradication of local vectors in isolated situations has been achieved elsewhere in the past using larvicides (McMahon, 1967; Davies, 1994), including the eradication of the Djodji form of S. sanctipauli Vajime \& Dunbar (Simuliidae) in West Africa (Walsh, 1990a; Fiasorgbor et al., 1992). The success of local elimination has depended upon the accessibility of breeding sites to control operations, and their concomitant isolation from vector immigration (Garms et al., 1989; Walsh, 1990b). The distribution of breeding sites on Bioko has been described by McCall et al. (1998) with special reference to their accessibility to possible vector control operations, but very little is known about the potential geographical isolation of the Bioko population of vectors (Post et al., 1995).

In 1990 an onchocerciasis chemotherapy programme was established as a joint initiative by the governments of Equatorial Guinea (Ministry of Health) and Spain (Spanish International Cooperation Agency), and the microfilaricidal drug ivermectin has been distributed once a year to the entire population of Bioko since 1995. The clinical effects have been monitored (Mas et al., 1995), but the parasitological effects and effects on transmission have not been assessed. There are undoubted clinical benefits to ivermectin treatment although it is generally not clear whether ivermectin on its own can interrupt transmission of the parasite (Boatin et al., 1998). Hence, the World Health Organization African Programme for Onchocerciasis Control (APOC) has a strategy not only to support ivermectin distribution in onchocerciasis-endemic countries, but also to effect focal vector eradication where appropriate in isolated areas (Remme, 1995). However, any chance of blocking transmission on Bioko by vector eradication will be affected by the possibility of recolonization by flies from the mainland, and similarly any potential effect of ivermectin distribution on transmission will be moderated by the possibility of immigrant infective flies.

Bioko is the only island with endemic onchocerciasis transmission and, as such, represents a special case of isolation (fig. 1). The Atlantic ocean is to the west of Bioko, and to the south lie the islands of Príncipe (which is the nearest, at $210 \mathrm{~km}$ SSW), São Tomé and Annobón, in that order. Simulium damnosum s.l. has not been found on any of these islands (respectively, R.J. Post unpublished data; dos Sántos Gracio, 1998; J. Mas, unpublished data), and hence the only potential sources of reinvading flies are on the mainland near Mount Cameroon (40 km NNE) and the other coastal parts of Cameroon $80-130 \mathrm{~km}$ to the east. There are almost no published records of the distribution of the various cytospecies of the $S$. damnosum complex in southern and eastern Cameroon, including the Mount Cameroon area. However, Traore-Lamizana \& Lemasson (1987) and Mafuyai et al. (1996) review the general situation for northern Cameroon and Nigeria respectively, and Traore-Lamizana et al. (2001) have reviewed the cytotaxonomy of the $S$. squamosum subcomplex for both countries.

In this paper we will describe the chromosomal, morphological and molecular (DNA and isoenzymes) characteristics of $S$. damnosum s.l. from Bioko in order to determine its taxonomic status and its distinctiveness from continental populations.

\section{Materials and methods}

\section{Collection of materials}

Larvae and pupae were collected from riverine breeding sites on Bioko in May and November 1989, April-May and July 1996 (table 1). Larvae were fixed in Carnoy's solution at $4{ }^{\circ} \mathrm{C}$ for cytotaxonomic studies, and pupae were kept in a dark humid cage at room temperature until adults emerged. Neonate adults were fixed in $100 \%$ ethanol and kept at $4^{\circ} \mathrm{C}$ for DNA analysis (Post et al., 1993) or frozen at $-40^{\circ} \mathrm{C}$ or $-70^{\circ} \mathrm{C}$ for isoenzyme analysis. For comparison, additional collections of larvae and neonate adults were used from Cameroon (table 2) and other parts of mainland West Africa, including; S. squamosum (Enderlein) (Simuliidae) from R. Amou at Amou Oblo Togo $\left(07^{\circ} 24^{\prime} \mathrm{N} / 00^{\circ} 53^{\prime} \mathrm{E}\right)$ collected by R.A. Cheke on 22.iii.90; S. yahense from R. Mpebo at Akakro Côte d'Ivoire $\left(05^{\circ} 32^{\prime} \mathrm{N} / 04^{\circ} 28^{\prime} \mathrm{W}\right)$ collected by M.D. Wilson on 05.x.90, and from Kenema waterfall Sierra Leone $\left(07^{\circ} 54^{\prime} \mathrm{N} / 11^{\circ} 14^{\prime} \mathrm{W}\right)$ collected by R.J. Post on 20.vii.85; S. sanctipauli from R. Sassandra at Koperagui Côte d'Ivoire $\left(05^{\circ} 38^{\prime} \mathrm{N} / 06^{\circ} 38^{\prime} \mathrm{W}\right)$ collected by M.D. Wilson on 02.x.90; S. leonense Boakye, Post \& Mosha (Simuliidae) and/or $S$. soubrense Vajime \& Dunbar (Simuliidae) from R. Rokel near Makpankaw Sierra Leone $\left(08^{\circ} 44^{\prime} \mathrm{N} / 11^{\circ} 56^{\prime} \mathrm{W}\right)$ collected by R.J. Post on 05.xii.88; S. sirbanum Vajime \& Dunbar (Simuliidae) from R. Niger at Tienfala Mali $\left(12^{\circ} 43^{\prime} \mathrm{N} / 07^{\circ} 44^{\prime} \mathrm{W}\right)$ collected by M.D. Wilson on 15.xi.88; 


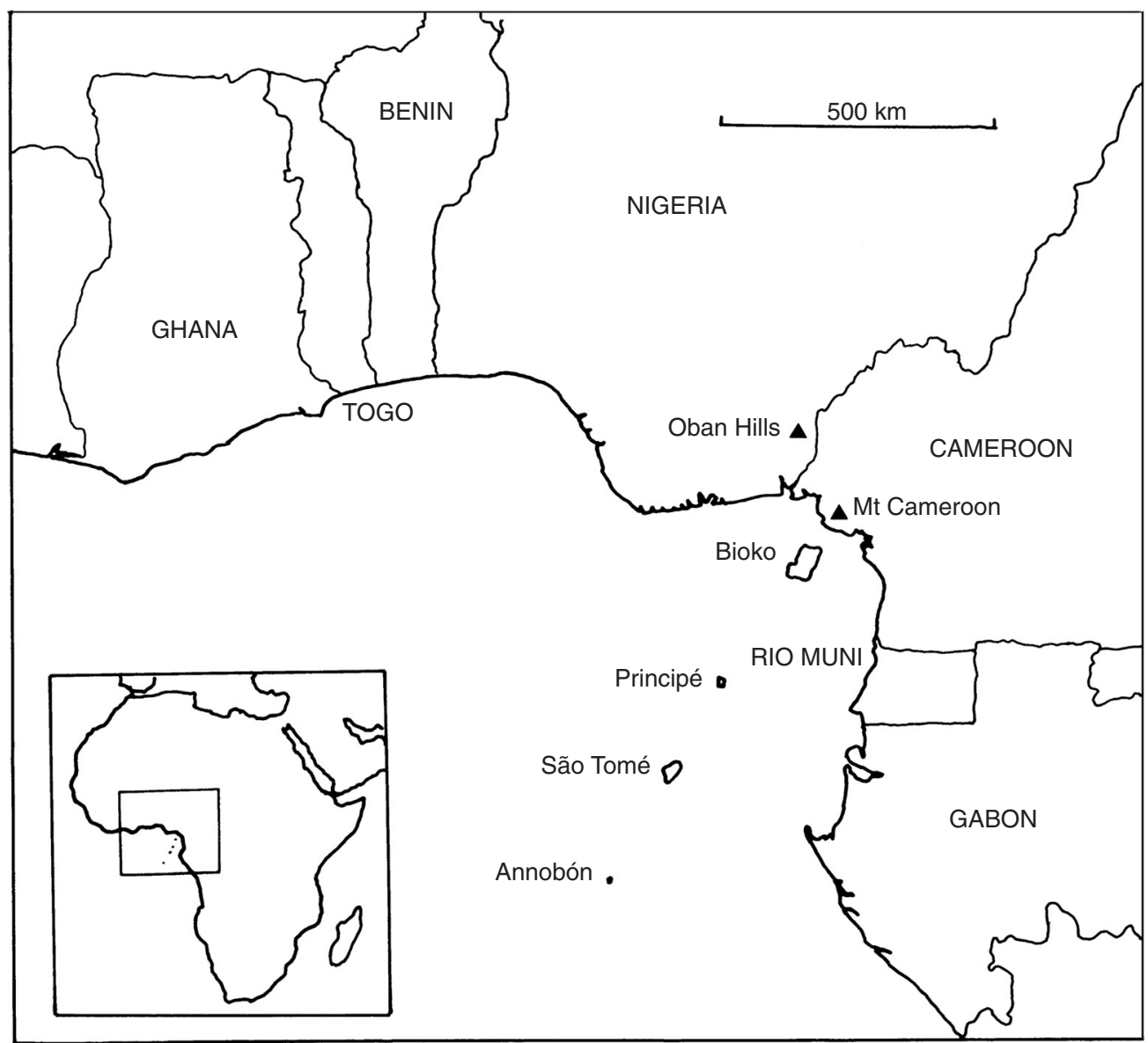

Fig. 1. Map showing the location of the island of Bioko in the Gulf of Guinea. The Republic of Equatorial Guinea consists of Rio Muni and the islands of Bioko and Annobón.

and cytotaxonomically uncharacterized material from R. Pra at Hemang Ghana $\left(05^{\circ} 11^{\prime} \mathrm{N} / 01^{\circ} 36^{\prime} \mathrm{W}\right)$ and from R. Tano at Abesim waterworks Ghana $\left(07^{\circ} 15^{\prime} \mathrm{N} / 02^{\circ} 15^{\prime} \mathrm{W}\right)$ collected respectively on $01 . i i .97$ and 29.i.97 by A.K. Tetteh and M.D. Wilson.

\section{Cytotaxonomic analysis of larvae}

Larval silk glands were dissected out and the polytene chromosomes prepared according to standard methodologies (Boakye et al., 1993). Sibling species were identified and intraspecific variation was assessed according to the pattern of fixed and polymorphic inversions, which were scored with reference to the nomenclature and standards published by Vajime \& Dunbar (1975), taking into account later modifications summarized by Boakye (1993) and Traore-Lamizana et al. (2001).

\section{Zymotaxonomy}

Flies were either collected at human bait by J. Mas at Sampaca on 28.viii.96, or reared from pupae collected by P.J. McCall and R.A. Cheke on 17/18.v.96 from a number of rivers off the main road, along the west of the island between R. Tiburones and R. Bisoco. Frozen preserved flies were later individually homogenized in buffer to extract water soluble enzymes. The extract was subjected to cellulose acetate electrophoresis and stained for enzyme activity according to the methods of Thomson et al. (1989). Flies were characterized for phosphoglucomutase and trehalase, which together allow the differentiation of $S$. squamosum and $S$. yahense from each other and from all other West African sibling species (Meredith \& Townson, 1981).

\section{Morphotaxonomy}

Adult flies of both sexes that had been reared from pupae or females collected at human bait (table 4) were preserved in either $100 \%$ or $80 \%$ ethanol. The lengths of the antennae and thoraces were measured according to Garms (1978). The colour of the fore coxa was scored as either pale or dark and the arculus was scored as pale, intermediate or dark, as described by Wilson et al. (1993). The stem vein setae (wing tufts) were scored on a scale A-E (A, all pale; $\mathrm{B}$, up to five dark hairs; C, mixed; D, up to five pale hairs; E, all dark; and O, character missing) according to Kurtak et al. (1981), and the scutellar hairs, ninth abdominal tergite setae, basicostal setae, and postcranial hairs were scored in a similar way but considering all mixtures together (A, all pale; $\mathrm{C}$, mixed; $\mathrm{E}$, all dark; and $\mathrm{O}$, character missing), as described by Wilson et al. (1993). 
Table 1. Karyotype analysis of Simulium larval samples from Bioko.

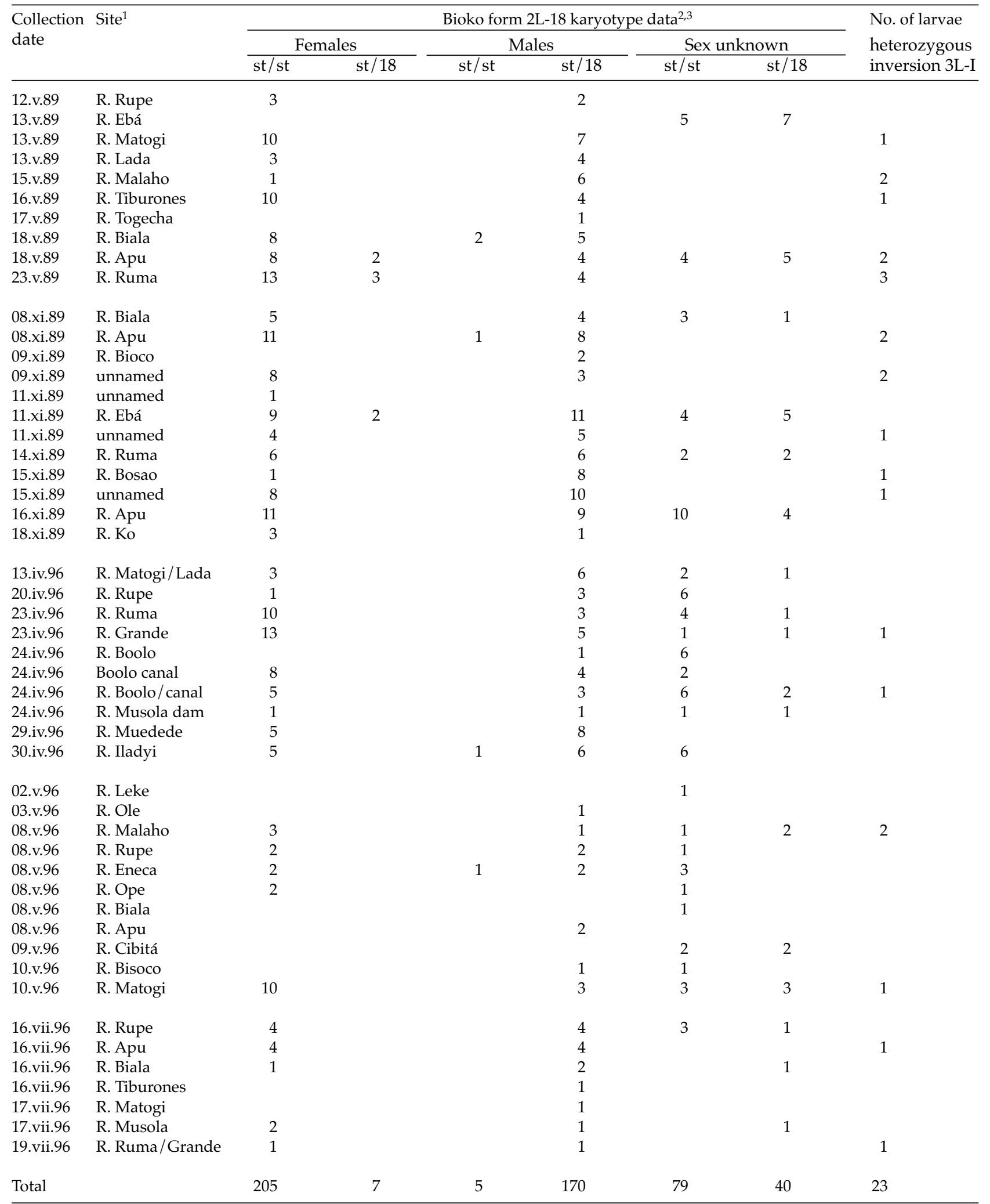

${ }^{1}$ Details of locations can be found in McCall et al. (1998).

${ }^{2}$ st indicates standard (i.e. uninverted) sequence as defined by Vajime \& Dunbar (1975).

${ }^{3} 2 \mathrm{~L}-18 / 18$ homozygotes were never found. 
Table 2. Karyotype analysis of Simulium larval samples from Mount Cameroon area.

\begin{tabular}{|c|c|c|c|c|c|c|c|c|c|c|}
\hline \multirow{3}{*}{$\begin{array}{l}\text { Collection } \\
\text { date }\end{array}$} & \multirow[t]{3}{*}{ Site } & \multirow{3}{*}{$\begin{array}{l}\text { Coordinates } \\
\text { Lat./Long. }\end{array}$} & \multicolumn{3}{|c|}{ Cytospecies id ${ }^{1}$} & \multicolumn{4}{|c|}{ S. squamosum 2L-18 karyotype data ${ }^{2}$} & \multirow{3}{*}{$\begin{array}{l}\text { Other polymorphic } \\
\text { inversions }\end{array}$} \\
\hline & & & \multirow[t]{2}{*}{ dam } & \multirow[t]{2}{*}{ meng } & \multirow[t]{2}{*}{$s q u$} & \multicolumn{2}{|c|}{ females } & males & unknown & \\
\hline & & & & & & st/st & st $/ 18$ & st/st $\quad$ st/18 & st/st $\quad$ st $/ 18$ & \\
\hline \multicolumn{11}{|c|}{ North of Mount Cameroon } \\
\hline 05.v.89 & Bikili dam & $04^{\circ} 37^{\prime} / 09^{\circ} 21^{\prime}$ & 6 & & 7 & 4 & & 3 & & $3 \mathrm{~L}-7$ \\
\hline 06.viii.90 & Bikili dam & $04^{\circ} 37^{\prime} / 09^{\circ} 21^{\prime}$ & 5 & & 3 & 2 & 1 & & & 1S-22, 1L-15 \& 3L-7 \\
\hline 05.viii.90 & R. Menge & $04^{\circ} 45^{\prime} / 09^{\circ} 29^{\prime}$ & & & 8 & 4 & & 4 & & \\
\hline 07.v.01 & R. Menge & $04^{\circ} 45^{\prime} / 09^{\circ} 29^{\prime}$ & & & 3 & & & & 3 & \\
\hline 07.v.01 & Bolo Moboka & $04^{\circ} 52^{\prime} / 09^{\circ} 28^{\prime}$ & & & 3 & 2 & & 1 & & \\
\hline 08.v.01 & R. Kake & $04^{\circ} 39^{\prime} / 09^{\circ} 25^{\prime}$ & 6 & & & & & & & \\
\hline 08.v.01 & R. Bile & $04^{\circ} 35^{\prime} / 09^{\circ} 21^{\prime}$ & & & 5 & 3 & & 1 & 1 & \\
\hline 09.v.01 & Trib. of Njanje & $04^{\circ} 24^{\prime} / 09^{\circ} 19^{\prime}$ & & 1 & & & & & & \\
\hline 10.v.01 & R. Kumba & $04^{\circ} 32^{\prime} / 09^{\circ} 28^{\prime}$ & & & 6 & 1 & & 4 & 1 & \\
\hline
\end{tabular}

North of Mount Cameroon

Bikili dam

05.viii.90 R. Menge

07.v.01 R. Menge

07.v.01 Bolo Moboka

08.v.01

08.v.01

09.v.01

10.v.01

R. Bile

Trib. of Njanje

\begin{abstract}
$04^{\circ} 37^{\prime} / 09^{\circ} 21^{\prime}$
$04^{\circ} 37^{\prime} / 09^{\circ} 21^{\prime}$

$04^{\circ} 45^{\prime} / 09^{\circ} 29^{\prime}$

$04^{\circ} 45^{\prime} / 09^{\circ} 29^{\prime}$

$04^{\circ} 52^{\prime} / 09^{\circ} 28^{\prime}$

$04^{\circ} 39^{\prime} / 09^{\circ} 25^{\prime}$

$04^{\circ} 35^{\prime} / 09^{\circ} 21^{\prime}$

$04^{\circ} 24^{\prime} / 09^{\circ} 19^{\prime}$
\end{abstract}

R. Kumba $\quad 04^{\circ} 32^{\prime} / 09^{\circ} 28^{\prime}$

Southwest of Mount Cameroon

$\begin{array}{lllr}08 . v i i .96 & \text { R. Sanje } & 04^{\circ} 14^{\prime} / 09^{\circ} 00^{\prime} & 4 \\ \text { 08.vii.96 } & \text { R. Mossingili } & 04^{\circ} 15^{\prime} / 08^{\circ} 59^{\prime} & 7 \\ \text { 11.v.01 } & \text { R. Oonge } & 04^{\circ} 16^{\prime} / 08^{\circ} 57^{\prime} & 5 \\ \text { 13.v.01 } & \text { R. Sanje } & 04^{\circ} 14^{\prime} / 09^{\circ} 00^{\prime} & 11\end{array}$

Southeast of Mount Cameroon

$\begin{array}{lll}\text { 26.ii.91 } & \text { R. Ombe } & 04^{\circ} 05^{\prime} / 09^{\circ} 17^{\prime} \\ \text { 03.iii.91 } & \text { R. Yoke } & 04^{\circ} 18^{\prime} / 09^{\circ} 26^{\prime} \\ \text { 31.i.94 } & \text { R. Limbe } & 04^{\circ} 01^{\prime} / 09^{\circ} 12^{\prime} \\ \text { 07.vii.96 } & \text { R. Limbe } & 04^{\circ} 02^{\prime} / 09^{\circ} 12^{\prime} \\ \text { 07.vii.96 } & \text { R. Benoe } & 04^{\circ} 05^{\prime} / 09^{\circ} 19^{\prime} \\ \text { 07.vii.96 } & \text { R. Likomba } & 04^{\circ} 05^{\prime} / 09^{\circ} 20^{\prime} \\ \text { 07.vii.96 } & \text { R. Ombe } & 04^{\circ} 05^{\prime} / 09^{\circ} 17^{\prime} \\ \text { 07.vii.96 } & \text { R. Yoke } & 04^{\circ} 18^{\prime} / 09^{\circ} 26^{\prime} \\ \text { 06.v.01 } & \text { R. Benoe } & 04^{\circ} 07^{\prime} / 09^{\circ} 18^{\prime} \\ \text { 06.v.01 } & \text { R. Ndongo } & 04^{\circ} 05^{\prime} / 09^{\circ} 21^{\prime} \\ \text { 10.v.01 } & \text { R. Yoke } & 04^{\circ} 18^{\prime} / 09^{\circ} 26^{\prime} \\ \text { 12.v.01 } & \text { R. Limbe } & 04^{\circ} 01^{\prime} / 09^{\circ} 12^{\prime} \\ \text { 13.v.01 } & \text { R. Essuke } & 04^{\circ} 05^{\prime} / 09^{\circ} 18^{\prime} \\ \text { 13.v.01 } & \text { R. Moliwe } & 04^{\circ} 04^{\prime} / 09^{\circ} 15^{\prime} \\ \text { 13.v.01 } & \text { R. Ombe } & 04^{\circ} 05^{\prime} / 09^{\circ} 17^{\prime}\end{array}$

Total

\begin{tabular}{|c|c|c|c|c|c|c|c|c|c|c|}
\hline \multirow{3}{*}{$\begin{array}{l}\text { Collection } \\
\text { date }\end{array}$} & \multirow[t]{3}{*}{ Site } & \multirow{3}{*}{$\begin{array}{l}\text { Coordinates } \\
\text { Lat./Long. }\end{array}$} & \multicolumn{3}{|c|}{ Cytospecies id ${ }^{1}$} & \multicolumn{4}{|c|}{ S. squamosum 2L-18 karyotype data ${ }^{2}$} & \multirow{3}{*}{$\begin{array}{l}\text { Other polymorphic } \\
\text { inversions }\end{array}$} \\
\hline & & & \multirow[t]{2}{*}{ dam } & \multirow[t]{2}{*}{ meng } & \multirow[t]{2}{*}{$s q u$} & \multicolumn{2}{|c|}{ females } & males & unknown & \\
\hline & & & & & & st/st & st/18 & st/st st/18 & st/st st/18 & \\
\hline \multicolumn{11}{|c|}{ North of Mount Cameroon } \\
\hline 05.v.89 & Bikili dam & $04^{\circ} 37^{\prime} / 09^{\circ} 21^{\prime}$ & 6 & & 7 & 4 & & 3 & & $3 \mathrm{~L}-7$ \\
\hline 06.viii.90 & Bikili dam & $04^{\circ} 37^{\prime} / 09^{\circ} 21^{\prime}$ & 5 & & 3 & 2 & 1 & & & 1S-22, 1L-15 \& 3L-7 \\
\hline 05.viii.90 & R. Menge & $04^{\circ} 45^{\prime} / 09^{\circ} 29^{\prime}$ & & & 8 & 4 & & 4 & & \\
\hline 07.v.01 & R. Menge & $04^{\circ} 45^{\prime} / 09^{\circ} 29^{\prime}$ & & & 3 & & & & 3 & \\
\hline 07.v.01 & Bolo Moboka & $04^{\circ} 52^{\prime} / 09^{\circ} 28^{\prime}$ & & & 3 & 2 & & 1 & & \\
\hline 08.v.01 & R. Kake & $04^{\circ} 39^{\prime} / 09^{\circ} 25^{\prime}$ & 6 & & & & & & & \\
\hline 08.v.01 & R. Bile & $04^{\circ} 35^{\prime} / 09^{\circ} 21^{\prime}$ & & & 5 & 3 & & 1 & 1 & \\
\hline 09.v.01 & Trib. of Njanje & $04^{\circ} 24^{\prime} / 09^{\circ} 19^{\prime}$ & & 1 & & & & & & \\
\hline 10.v.01 & R. Kumba & $04^{\circ} 32^{\prime} / 09^{\circ} 28^{\prime}$ & & & 6 & 1 & & 4 & 1 & \\
\hline
\end{tabular}
5 11

\begin{tabular}{|c|c|c|c|c|c|c|c|c|c|c|}
\hline \multirow{3}{*}{$\begin{array}{l}\text { Collection } \\
\text { date }\end{array}$} & \multirow[t]{3}{*}{ Site } & \multirow{3}{*}{$\begin{array}{l}\text { Coordinates } \\
\text { Lat./Long. }\end{array}$} & \multicolumn{3}{|c|}{ Cytospecies id ${ }^{1}$} & \multicolumn{4}{|c|}{ S. squamosum $2 \mathrm{~L}-18$ karyotype data ${ }^{2}$} & \multirow{3}{*}{$\begin{array}{l}\text { Other polymorphic } \\
\text { inversions }\end{array}$} \\
\hline & & & \multirow[t]{2}{*}{ dam } & \multirow[t]{2}{*}{ meng } & \multirow[t]{2}{*}{$s q u$} & \multicolumn{2}{|c|}{ females } & males & unknown & \\
\hline & & & & & & st/st & st $/ 18$ & st/st $\quad$ st $/ 18$ & st/st $\quad$ st $/ 18$ & \\
\hline \multicolumn{11}{|c|}{ North of Mount Cameroon } \\
\hline 05.v.89 & Bikili dam & $04^{\circ} 37^{\prime} / 09^{\circ} 21^{\prime}$ & 6 & & 7 & 4 & & 3 & & $3 \mathrm{~L}-7$ \\
\hline 06.viii.90 & Bikili dam & $04^{\circ} 37^{\prime} / 09^{\circ} 21^{\prime}$ & 5 & & 3 & 2 & 1 & & & 1S-22, 1L-15 \& 3L-7 \\
\hline 05.viii.90 & R. Menge & $04^{\circ} 45^{\prime} / 09^{\circ} 29^{\prime}$ & & & 8 & 4 & & 4 & & \\
\hline 07.v.01 & R. Menge & $04^{\circ} 45^{\prime} / 09^{\circ} 29^{\prime}$ & & & 3 & & & & 3 & \\
\hline 07.v.01 & Bolo Moboka & $04^{\circ} 52^{\prime} / 09^{\circ} 28^{\prime}$ & & & 3 & 2 & & 1 & & \\
\hline 08.v.01 & R. Kake & $04^{\circ} 39^{\prime} / 09^{\circ} 25^{\prime}$ & 6 & & & & & & & \\
\hline 08.v.01 & R. Bile & $04^{\circ} 35^{\prime} / 09^{\circ} 21^{\prime}$ & & & 5 & 3 & & 1 & 1 & \\
\hline 09.v.01 & Trib. of Njanje & $04^{\circ} 24^{\prime} / 09^{\circ} 19^{\prime}$ & & 1 & & & & & & \\
\hline 10.v.01 & R. Kumba & $04^{\circ} 32^{\prime} / 09^{\circ} 28^{\prime}$ & & & 6 & 1 & & 4 & 1 & \\
\hline
\end{tabular}

1 dam, S. damnosum s.str.; meng, S. mengense; squ, S. squamosum (no other cytospecies were identified).

${ }^{2} 2 \mathrm{~L}-18 / 18$ homozygotes were never found.

\section{DNA extraction and restriction digestion}

DNA was extracted from individual flies using the protocol of Flook et al. (1992) and was suitable for EcoRI restriction enzyme digestion using manufacturer's instructions. To avoid star activity of enzymes, a low enzyme

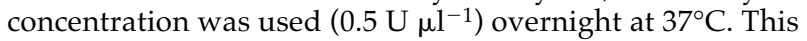
DNA from individual flies was used in Southern blot analysis with hybridization to probe pSO11 (see below). To prepare high quality genomic DNA from 10-100 flies for the construction of a genomic library or melting curve analysis (see below), the method of Bingham et al. (1981) was used. Both methods yielded approximately $1 \mu \mathrm{g}$ DNA per fly.

\section{Agarose gel electrophoresis and Southern blotting}

Agarose gels (0.9\% FMC SeaKem) were prepared using 1 $\times$ TAE buffer and run overnight at $2 \mathrm{~V} \mathrm{~cm}^{-1}$. Post-electrophoresis gels were prepared by denaturation and neutralisation (Southern, 1975; Sambrook et al., 1989).
Depurination in $\mathrm{HCl}$ was used initially as a preliminary to denaturation, but later limited exposure to ultraviolet light on a transilluminator was used instead. Three methods were used to transfer DNA to nitrocellulose filters (Biotrace NT), including capillary transfer, vacuum blotting and pressure blotting. Of these, capillary blotting was used preferentially because of superior band resolution in autoradiography.

\section{DNA-DNA hybridization}

Insert DNA from EcoRI digested cloned probes pSO11 (for Southern blots), pSY29 and pBS22 (both for melting curve analysis) (see below) was recovered from agarose gels and radiolabelled with $\left[-\mathrm{P}^{32}\right]$-dCTP using random-primed labelling. Filters were prehybridized $(5 \times$ SSC, $50 \%$ deionized formamide, $5 \times$ Denhardt's, $0.05 \mathrm{M}$ phosphate buffer, $50 \mathrm{mg} \mathrm{ml}^{-1}$ denatured herring sperm DNA) at $42^{\circ} \mathrm{C}$ for $24 \mathrm{~h}$, and the buffer was changed $(5 \times \mathrm{SSC}, 50 \%$ deionized formamide, $5 \times$ Denhardt's, $0.02 \mathrm{M}$ phosphate 
buffer, $100 \mathrm{mg} \mathrm{ml}^{-1}$ denatured herring sperm DNA) immediately before hybridization. Labelled probes were denatured at $100^{\circ} \mathrm{C}$ and added at a concentration of $1 \times$ $10^{7}-1 \times 10^{8} \mathrm{cpm} \mathrm{cm}^{-2}$, and hybridization continued overnight (Southern blots) or for $24 \mathrm{~h}$ (melting curve analysis, to ensure saturation of all binding sites) at $42{ }^{\circ} \mathrm{C}$. Filters were washed in various concentrations of SSC, $0.1 \%$ SDS at different temperatures and exposed to Fuji RX film at $-45^{\circ} \mathrm{C}$ or $-70^{\circ} \mathrm{C}$.

\section{Melting curve analysis}

Genomic DNA (100 ng) was resuspended in $6 \times$ SSC and denatured at $100^{\circ} \mathrm{C}$ for $10 \mathrm{~min}$ before application to a nitrocellulose filter using a dot-blot manifold (Kafatos et al., 1979). Filters were dried and hybridized to radiolabelled pSY29 or pBS22 insert DNA (see above) and subsequently washed nine times in $0.1 \times$ SSC $+0.1 \%$ SDS at increasing temperatures (steps of $5^{\circ} \mathrm{C}$ ), and the amount of DNA-DNA hybridization after each wash was compared by Cerenkov counting for 1 min (Kafatos et al., 1979; Sambrook et al., 1989). Two replicates of each sample were used. Analysis of the hybrid dissociation data was performed on the combined replicate data using Maximum Likelihood Programme (Numerical Algorithms Group, MLP user manual). The data best fitted the generalized logistic equation, $\mathrm{y}=\mathrm{A}+\mathrm{C} /(1+\exp (-\mathrm{B}(\mathrm{x}-\mathrm{M})))$, where the parameter $A$ is the lower asymptote, $A+C$ is the upper asymptote, $\mathrm{X}=\mathrm{M}$ is the point of inflection, and $\mathrm{B}$ is the slope parameter. Statistical analysis of fitted curves was performed by parallel curve analysis. Using this approach the statistical significance of differences between linear parameters (A and $\mathrm{C}$, corresponding to copy number) and non-linear parameters $(\mathrm{M}$ and $\mathrm{B}$, corresponding to melting temperatures of sequences) could be examined.

\section{Source and characterization of DNA probes}

The DNA probe pSO11 was originally isolated from $S$. leonense for its potential use in sibling species identification (Post \& Flook, 1992), because it is repetitive and shows copy number variation between sibling species. Sequencing revealed a composite pattern of repetition (Post et al., 1992), resembling the organization found in certain transposable elements (Flook \& Post, 1997), and EcoRI Southern blot analysis of genomic DNA revealed a hypervariable banding profile. To isolate additional DNA probes, a series of genomic libraries was prepared using genomic DNA from three sources; S. squamosum and S. damnosum s.str. from Cameroon (collected simultaneously from Bikili Dam, 05 May 1989, and identified morphologically as adults Wilson et al., 1994), and S. damnosum complex from Bioko (collected Rio Apu, 18 May 1989), see table 1. Libraries were prepared as described by Flook (1992). Over 100 recombinants were selected after primary screenings by differential hybridization, arranged in ordered arrays and rescreened. Plasmid DNA was prepared from recombinants that showed potentially species specific hybridization patterns. These DNA preparations were radiolabelled and hybridized to genomic DNA dot-blot and Southern blot filters containing different sibling species. In particular, differences in hybridization between specimens from Bioko and other S. squamosum subcomplex DNA samples were investigated.

\section{Results}

\section{Cytotaxonomy}

A total of 506 larvae from 50 samples from Bioko was examined chromosomally (table 1 ). No new inversions were found. All populations were found to be similar to each other, and closely related to S. squamosum and S. yahense. Full karyotype analysis did not reveal any fixed inversion differences, but the Bioko populations were found to be cytotaxonomically distinct from both $S$. squamosum and S. yahense in terms of sex-linkage of inversion IIL-18. Throughout West Africa, IIL-18 is normally absent from S. squamosum and strongly X-linked in S. yahense (Boakye, 1993), but when inversion IIL-18 is found in S. squamosum it is never sexlinked. This is the pattern that was found in larvae of $S$. squamosum from sites sampled near the coast of Cameroon, around Mount Cameroon (table 2). Simulium yahense was not identified from sites visited in Cameroon, but it has been reported by Mafuyai et al. (1996) from southern Nigeria on the border with Cameroon, where it shows normal X-linkage of IIL-18. The difference is that on Bioko, IIL-18 was clearly Ylinked in all populations (table 1) with an $X$ frequency of $1.7 \%$ and a $Y$ frequency of $97.1 \%$. This means that using normal cytotaxonomic criteria (Boakye, 1993), females from Bioko would be identified as $S$. squamosum and males as $S$. yahense. Hence it is not possible on chromosomal evidence alone to determine whether the Bioko populations are an island race of $S$. squamosum, $S$. yahense or a new species. Besides IIL-18, the only polymorphic inversion found on Bioko was IIIL-I (see Post, 1986), although this was rare (4.5\% heterozygotes) and never observed homozygously (table 1). This polymorphism was also observed in a single larva of $S$. squamosum from Cameroon, but this observation probably has no taxonomic significance because this inversion, whilst rare, has been found in most of the West African cytospecies (Vajime \& Dunbar, 1975; Post, 1986; Boakye, 1993).

\section{Zymotaxonomy}

Of 91 flies collected from human bait during August 1996, none stained for phosphoglucomutase and only 67 stained for trehalase. All 67 trehalase-positive flies were identified as being either S. squamosum or S. yahense (which cannot be distinguished by trehalase). The results for flies collected during May 1996 (and experimental control flies) are shown in table 3 . The 14 experimental control flies from the rivers Pra and Tano in southern Ghana were shown to be a mixture of $S$. yahense and some other cytospecies (but not S. squamosum). This is broadly consistent with previous cytotaxonomic identifications from these rivers (R.J. Post, unpublished). Simulium yahense is the most common species in the upper Tano, followed by S. squamosum, S. sirbanum and $S$. damnosum s.str. The most common species on the Lower Pra is S. sanctipauli, followed by S. damnosum, S. soubrense, S. squamosum and S. yahense. All 25 flies from Bioko which stained for both phosphoglucomutase and trehalase could be identified as $S$. yahense according to the criteria defined by Meredith \& Townson (1981).

\section{Morphotaxonomy}

Totals of 58 male and 606 female flies were examined from 20 samples. Not all flies could be scored for all 
Table 3. Cellulose acetate electrophoresis identification of neonate flies from Bioko and control sites.

\begin{tabular}{|c|c|c|c|c|}
\hline $\begin{array}{l}\text { PGM/TRE isozyme }{ }^{1} \\
\text { Species identity }\end{array}$ & $\begin{array}{l}\mathrm{C} / \mathrm{B} \\
\text { sanctipauli }^{2}\end{array}$ & $\begin{array}{l}\mathrm{B} 1 / \mathrm{A} \\
\text { yahense }\end{array}$ & $\begin{array}{l}\text { ?/ } \mathrm{A}^{3} \\
\text { squamosum } \\
\text { or yahense }\end{array}$ & Total \\
\hline \multicolumn{5}{|l|}{ Source } \\
\hline \multicolumn{5}{|l|}{ Ghana } \\
\hline R. Pra at Hemang & 7 & 1 & 0 & 8 \\
\hline R. Tano at Abesim & 2 & 4 & 0 & 6 \\
\hline Bioko & 0 & 25 & 9 & 34 \\
\hline
\end{tabular}

characters due to missing body parts. Two female flies had a few pale hairs in their wing tufts (score D), and one had lost its hairs, but otherwise all female flies examined had entirely dark wing tufts $(n=603)$, entirely dark basicostal setae $(n=$ $524)$, entirely dark postcranial hairs $(n=606)$, a dark arculus $(n=383)$ and dark fore coxae $(n=606)$. In most specimens the colour of the setae of the scutellum $(n=593)$ and ninth abdominal tergite $(n=415)$ was all dark, but 13 and 7 specimens had mixed setae respectively (table 4 ). The values of the thorax length:antenna length ratios for females ranged from 1.77 to 2.07 , but most were in the range $1.90-2.00$, consistent with other populations of S. yahense (Garms \& Zillman, 1984). The antennae of all females lacked compression, consistent with membership of the forest group of flies (Garms \& Cheke, 1985), and were uniformly dark, except for the basal two segments and one third to one half of the third segment.
According to the setae of the ninth abdominal tergite, 415 female specimens would be identified as S. yahense and seven specimens as some other species (Garms \& Zillman, 1984; Fryauff \& Trpis, 1986; Davies et al., 1988). According to the qualitative characters (colour of ninth abdominal tergite setae, colour of arculus and colour of scutellar setae) described in the 'hierarchical' classification method of Wilson et al. (1993 - table 4) all female specimens that could be scored for all three characters $(n=258-$ table 5$)$ were identified as $S$. yahense except for five which had mixed abdominal setae, dark arculus and mixed scutellar setae. However, all five of these flies had a thorax length:antenna length ratio of less than 2.05 , which is considered to be the lower cut-off point for practical identification of $S$. squamosum (Garms \& Cheke, 1985), and a mean of 1.92 which is closer to the mode for S. yahense (1.98-Garms \& Zillman, 1984) than for S. squamosum (2.175 - Garms \&

Table 4. Morphological variation in adult females of the Bioko form of Simulium yahense.

\begin{tabular}{|c|c|c|c|c|c|c|c|c|c|c|c|c|c|c|}
\hline \multirow[t]{2}{*}{ Location } & \multirow[t]{2}{*}{ Date } & \multirow[t]{2}{*}{ Collector $^{1}$} & \multirow[t]{2}{*}{ Status $^{2}$} & \multirow{2}{*}{$\begin{array}{l}\text { Sample } \\
\text { size }\end{array}$} & \multirow{2}{*}{$\begin{array}{l}\text { Thorax } \\
\text { length }{ }^{3} \\
\text { mean (SD) }\end{array}$} & \multirow{2}{*}{$\begin{array}{l}\text { Antenna } \\
\text { length }{ }^{3} \\
\text { mean (SD) }\end{array}$} & \multicolumn{4}{|c|}{ Scutellar setae ${ }^{4}$} & \multicolumn{4}{|c|}{ Abdominal setae ${ }^{4}$} \\
\hline & & & & & & & A & $\mathrm{C}$ & $\mathrm{E}$ & $\mathrm{O}$ & A & $\mathrm{C}$ & $\mathrm{E}$ & $\mathrm{O}$ \\
\hline R. Musola & 22.iv.96 & RAC & Neonates & 1 & $1.02(-)$ & $0.56(-)$ & & & 1 & & & & 1 & \\
\hline R. Boolo, irrigation canal & 22.iv.96 & RAC & Neonates & 6 & $1.11(0.02)$ & $0.57(0.02)$ & & & 6 & & & & 6 & \\
\hline R. Grande & 23.iv.96 & RAC & Neonates & 13 & $1.09(0.03)$ & $0.57(0.02)$ & & & 13 & & & & 13 & \\
\hline R. Ruma & 23.iv.96 & RAC & Neonates & 50 & $1.09(0.04)$ & $0.57(0.03)$ & & & 50 & & & & 50 & \\
\hline R. Sampaca & 10.v.96 & RAC & At host & 12 & $1.11(0.08)$ & $0.56(0.04)$ & & & 12 & & & & 7 & 5 \\
\hline R. Apu at Izaguire & 16.vii.96 & MDW & Neonates & 82 & $1.01(0.09)$ & $0.53(0.05)$ & & 2 & 80 & & & 1 & 81 & \\
\hline R. Musola at Musola & 17.vii.96 & MDW & Neonates & 17 & $1.11(0.07)$ & $0.57(0.03)$ & & 1 & 16 & & & & 17 & \\
\hline R. Musola at Musola & 26.iv.99 & RAC & Neonates & 29 & $1.08(0.07)$ & $0.57(0.03)$ & & & 29 & & & & 12 & 17 \\
\hline Malabo airport pub & 24.vii.96 & MDW & At host & 8 & $1.07(0.05)$ & $0.55(0.02)$ & & & 8 & & & & 8 & \\
\hline R. Timbabe by airport rd & 22.vii.96 & MDW & Neonates & 13 & $1.10(0.05)$ & $0.57(0.01)$ & & & 13 & & & & 13 & \\
\hline R. Timbabe by airport rd & 22.vii.96 & MDW & At host & 65 & $1.05(0.07)$ & $0.53(0.03)$ & & 5 & 60 & & & & 65 & \\
\hline R. Ruma at Balancha de Riaba & 19.vii.96 & MDW & At host & 5 & $1.06(0.04)$ & $0.55(0.01)$ & & 1 & 4 & & & & 5 & \\
\hline $\begin{array}{l}\text { R. Ruma/Grande at } \\
\text { power-station }\end{array}$ & 19.vii.96 & MDW & At host & 34 & $1.06(0.06)$ & $0.54(0.02)$ & & 2 & 32 & & & 2 & 32 & \\
\hline R. Matogi & 17.vii.96 & MDW & At host & 36 & $1.08(0.05)$ & $0.55(0.02)$ & & 2 & 34 & & & 4 & 32 & \\
\hline R. Machuchumuano & 19.vii.96 & MDW & At host & 1 & $1.04(-)$ & $0.55(-)$ & & & 1 & & & & 1 & \\
\hline R.Apu & 22.iv.96 & RAC & At host & 16 & $1.14(0.05)$ & $0.58(0.02)$ & & & 16 & & & & 11 & 5 \\
\hline R. Apu & 26.iv.99 & RAC & At host & 107 & $1.13(0.06)$ & $0.57(0.03)$ & & & 107 & & & & 40 & 67 \\
\hline R. Apu & 27.iv.99 & RAC & At host & 40 & $1.10(0.07)$ & $0.57(0.02)$ & & & 40 & & & & 17 & 23 \\
\hline R. Ruma at Balacha de Riaba & 26.iv.99 & RAC & At host & 35 & $1.03(0.05)$ & $0.54(0.03)$ & & & 35 & & & & 1 & 34 \\
\hline R. Sampaca & 26.iv.99 & RAC & At host & 36 & $1.13(0.07)$ & $0.60(0.03)$ & & & 36 & & & & 3 & 33 \\
\hline Total & & & & 606 & & & & 13 & 593 & & & 7 & 415 & 184 \\
\hline
\end{tabular}

1Collectors were M.D. Wilson and R.A. Cheke.

${ }^{2}$ Specimens were either reared from pupae (neonates) or collected at human bait (at host).

${ }^{3}$ Lengths are in $\mathrm{mm}$.

${ }^{4}$ Setae were scored as described in the text. 
Table 5. List of all female flies exhibiting mixed colour characters.

\begin{tabular}{|c|c|c|c|c|c|}
\hline Site $^{1}$ & Specimen & Arculus $^{2}$ & Scutellar setae ${ }^{2}$ & Ninth tergite setae ${ }^{2}$ & Thorax:antenna ratio \\
\hline R. Apu (16.vii.96) & 2 & Dark & C & E & 2.18 \\
\hline \multirow[t]{3}{*}{ R. Timbabe (at host) } & 1 & Dark & $\mathrm{C}$ & $\mathrm{E}$ & 1.93 \\
\hline & 3 & Dark & $\mathrm{C}$ & $\mathrm{E}$ & 1.94 \\
\hline & 4 & Dark & $\mathrm{C}$ & $\mathrm{E}$ & 2.03 \\
\hline \multirow[t]{4}{*}{ R. Ruma/Grande } & 1 & Dark & $\mathrm{C}$ & $\mathrm{C}$ & 1.80 \\
\hline & 4 & Dark & $\mathrm{E}$ & $\mathrm{C}$ & 1.98 \\
\hline & 5 & Dark & $\mathrm{C}$ & $\mathrm{C}$ & 2.00 \\
\hline & 6 & Dark & $\mathrm{E}$ & $\mathrm{C}$ & 1.95 \\
\hline R. Musola (17.vii.96) & 1 & Dark & $\mathrm{C}$ & $\mathrm{E}$ & 2.20 \\
\hline
\end{tabular}

${ }^{1}$ See table 1 for details.

${ }^{2}$ See text for details of classification.

Cheke, 1985). Rare variation in these colour characters has already been described as potentially resulting in low levels (approximately 1\%) of misidentifications of some S. yahense populations elsewhere (Garms \& Zillman, 1984; Wilson et al., 1993). Therefore, in view of the thorax length:antenna length ratios, it is not considered that these few flies provide evidence for species other than S. yahense on Bioko.

All the 58 males examined were collected on 22 and 23 April 1996 from the first four sites listed in table 4. Fortyeight had scutal patterns of type IIIh and 10 of type IIIg, using the terminology described by Meredith et al. (1983), consistent with S. yahense (R.A. Cheke \& R. Garms, unpublished data), and distinguishing them from members of the S. sanctipauli subcomplex which usually have type I or type II scutal patterns (Meredith et al., 1983), or, in the case of the Beffa form of $S$. soubrense, type IV patterns. However, other cytospecies including $S$. squamosum and S. damnosum s. str., may have type III patterns. The 58 flies had a mean thorax length of 0.96 (range $0.86-1.08, \mathrm{SD}=0.04$ ) and a mean antenna length of 0.52 (range $0.46-0.58, S D=0.03$ ). The antennae were also typical of those of forest flies, being robust, broadening towards the tip and mostly dark, with thorax: antenna ratios ranging from 1.70 to 2.09. The arculus and scutellar hairs on these flies were consistently dark.

\section{Southern blot analysis with pSO11}

Totals of 334 flies from 24 Bioko samples and 141 flies from the mainland (including 75 S. squamosum from Cameroon) were examined for Southern blot variation using
EcoRI digested genomic DNA from individual flies hybridized to radiolabelled probe pSO11. The banding profiles were hypervariable, but the Bioko populations were found to have a unique $3.27 \mathrm{~kb}$ band (fig. 2) at a frequency of $90.4 \%$ of flies (table 6 ). Table 6 also includes estimates of relative copy number of pSO11 from Flook \& Post (1997). These show an obvious similarity between the Bioko specimens and S. squamosum in comparison with those other members of the complex which were tested.

\section{Melting curve analysis with pSY29 and pBS22}

Plasmid DNA was prepared from 23 clones, but in subsequent hybridization analyses only three clones showed any useful species-specific variation with respect to the Bioko flies. In all three cases clones pSY2, pSY29 and pBS22 showed stronger hybridization to Bioko flies than to either $S$. squamosum from Cameroon or S. yahense from Sierra Leone. In Southern blot analyses, hybridization smears were observed in hybridizations with these probes against all species, and no differential banding patterns were observed against EcoRI digested DNA, even after high stringency washes.

Two potentially taxa-specific sequences (pSY29 and pBS22) were investigated further by melting curve analysis. The melting curves are shown in fig. 3, and the estimated parameters from which these curves were constructed are shown in table 7. Statistical significance of these parameters was estimated by parallel curve analysis, and for both probes significant differences were detected between the

Table 6. pSo11-profile analysis.

\begin{tabular}{llccc}
\hline Population & Cytospecies & No. specimens & Relative copy no. $^{2}$ & Frequency 3.27kb band $^{2}$ \\
\hline Bioko & Bioko form & 334 & 1.0 & 0.904 \\
Mt Cameroon ${ }^{1}$ & S. squamosum & 75 & 1.5 & 0 \\
Côte d'Ivoire & S. sanctipauli & 18 & 4.22 & 0 \\
Sierra Leone & S. leonense + & 48 & 6.00 & 0 \\
& S. soubrense & & & \\
\hline
\end{tabular}

${ }^{1}$ Mt Cameroon samples are from Bikili Dam, and river Menge. The Simulium squamosum was separated from S. damnosum by morphological examination (Wilson et al., 1994).

${ }^{2}$ Data from Flook \& Post (1997). 


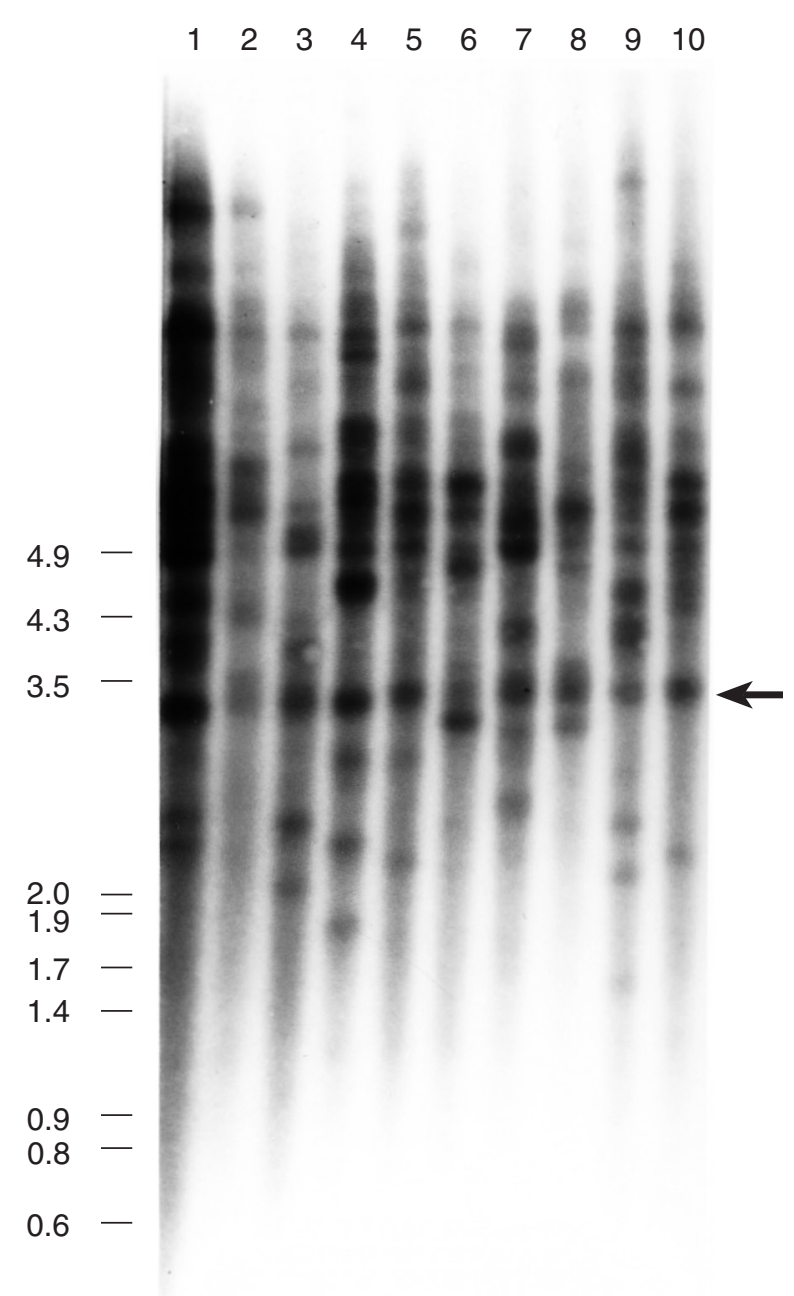

Fig. 2. Autoradiograph of Southern blot hybridization with $[\alpha-$ $\mathrm{P}^{32}$ ] labelled pSO11 probe. Lanes $1-10$ are genomic DNA extracted from individual adult females (caught at human bait near a tributary of the Rio Rupe, Bioko, 11 November 1989) digested with EcoRI. Arrow indicates the position of the high frequency $3.27 \mathrm{~kb}$ band.

common linear parameters. These significant differences indicate that the copy number of sequences hybridizing to the probes is significantly higher in the Bioko form of $S$. yahense than in the other members of the S. squamosum subcomplex examined. In contrast, no significant differences were detected between the non-linear parameters, indicating that there was little sequence divergence between repeats in the different species.

\section{Discussion}

Chromosomal evidence (supported by the relative copy number of pSO11) clearly indicates that the Bioko form belongs to the $S$. squamosum sub-complex although it was found to be genetically distinct from other members on the basis of the pattern of sex-linkage of inversion IIL-18. The evidence from the enzyme and morphological analyses clearly indicates a greater similarity to $S$. yahense than to $S$. squamosum (or any other West African cytospecies), which
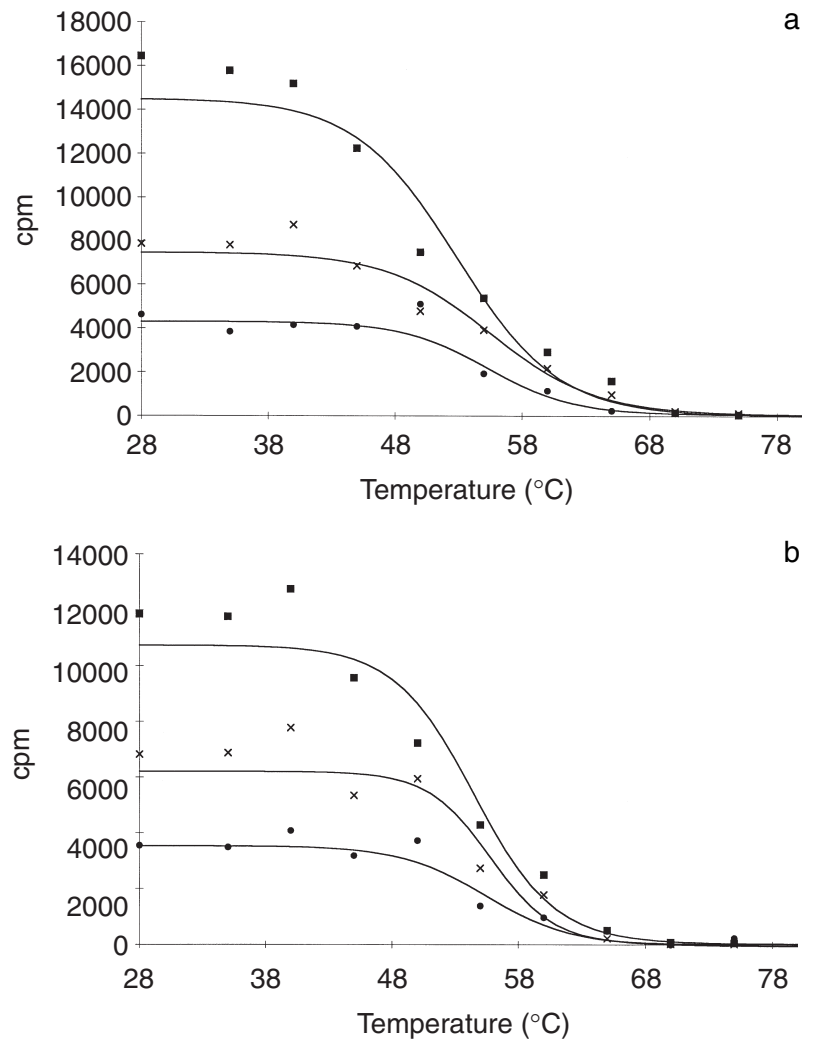

Fig. 3. Melting curves for pBS22 (a) and pSY29 (b). $\mathbf{n}$, Simulium yahense from Bioko; $\times$, S. squamosum from Cameroon (Bikili dam); $\bullet$ S. yahense from Sierra Leone (Kenema waterfall).

supports an earlier morphotaxonomic analysis of a single sample from the river Apu (Wilson et al., 1994). However, differences in copy number of two interspersed repetitive sequences (pBS22 and pSY29), the presence of the $3.27 \mathrm{~kb}$ pSO11 band at high frequency and the unique sexchromosome system, indicate that the Bioko populations are genetically distinctive. Together these differences indicate a high degree of genetic isolation of the Bioko form, but it cannot be concluded that this isolation is complete because none of these differences is fixed. In view of the evidence for a close relationship with $S$. yahense, in combination with some significant genetic differences from $S$. yahense and the uncertainty surrounding the exact degree of reproductive isolation (see below), it is proposed that these populations be referred to as 'the Bioko form of S. yahense'.

The genetic distinctiveness of the Bioko form could be the result of either geographical or reproductive isolation, or a combination of both, but because of the self-evident geographical separation, it is very difficult to determine the level of reproductive isolation of the Bioko form of $S$. yahense from mainland populations (i.e. the extent to which they have the potential to mate successfully and produce viable, fertile offspring). Whatever the extent of reproductive isolation, the evidence suggests that the level of geographical isolation must be very high.

It is impossible that flies could migrate to Bioko from the west (because there is only ocean), or from the islands to the south, not just because of the great distance, but primarily because they do not seem to occur on those islands. 
Table 7. Melting curve analysis of pSY29 and pBS22.

\begin{tabular}{|c|c|c|c|c|c|c|}
\hline \multicolumn{2}{|c|}{$\begin{array}{l}\text { Logistic curve Parameter } \\
\text { DNA Probe and species }\end{array}$} & \multirow{2}{*}{$\begin{array}{c}\mathrm{A} \\
-1.575\end{array}$} & \multirow{2}{*}{$\begin{array}{c}\text { B } \\
-0.2504\end{array}$} & \multirow{2}{*}{$\begin{array}{c}\mathrm{C} \\
14497\end{array}$} & \multirow{2}{*}{$\begin{array}{c}\mathrm{M} \\
52.842\end{array}$} & \multirow{2}{*}{$\begin{array}{r}\text { TM50 } \\
53\end{array}$} \\
\hline pBS22 & Bioko form & & & & & \\
\hline & S. yahense & 50.66 & -0.2972 & 4243.5 & 55.264 & 55 \\
\hline \multirow[t]{3}{*}{ pSY29 } & Bioko form & 34.838 & -0.3162 & 10696 & 54.495 & 54 \\
\hline & S. squamosum & 19.216 & -0.4038 & 6180.4 & 55.811 & 56 \\
\hline & S. yahense & -47.7 & -0.2955 & 3575.5 & 55.436 & 55 \\
\hline
\end{tabular}

The parameters A, B, C and M refer to the equation for the logistic curve (see Materials and methods), of which the melting temperature $\left(\mathrm{TM} 50^{\circ} \mathrm{C}\right)$ is M. The different species are: Bioko = Simulium damnosum s.l. from Bioko; S. squamosum from Cameroon (Bikili dam); and S. yahense from Sierra Leone (Kenema waterfall).

Meteorological factors reinforce Bioko's isolation, and severely limit the possibility of movement of flies from the mainland to the island. For almost the entire year the prevailing winds blow from the south or southwest across the island towards the mainland, and even at the height of the dry season the intertropical convergence zone rarely lies south of the island (Teran, 1962). Nosti (1942) illustrated average wind direction data for Malabo in 1940, which showed that northerly or easterly winds were generally uncommon, and this is a consistent pattern as confirmed by records from recent years. Between 1991 and 1995 the mean wind direction at Malabo for all months came from the southwest, except May 1991, September and November 1992 and April 1994 when it came from either the north or east (unpublished data from Servicio de Meteorologia ASECNA, Malabo). It is, therefore, unlikely that flies could easily migrate to Bioko from the north or east, because this is contrary to the usual prevailing winds. The northerly winds that do blow are usually sea-breezes (Nosti, 1947; Capuz, 1953), and hence do not blow all the way from the mainland. Occasional easterly winds are usually associated with linesqualls. In other parts of West Africa, the available evidence suggests that line-squalls do not carry migrating $S$. damnosum s.l. (Garms et al., 1982), which usually move with the prevailing winds (Garms et al., 1979, 1982, Baker et al., 1990). In Benin, line-squalls are usually followed by a decrease in fly numbers (Cheke \& Garms, 1983). It is of course true that Bioko must have been colonized at some time by $S$. damnosum s.l., but during the Pleistocene, Bioko was connected to Mount Cameroon by a land bridge (Jones, 1994) and hence there is no necessity to postulate a recent transoceanic colonization event.

Simulium yahense has not been recorded from continental sources (near the coast of Cameroon) of potentially migrant flies, and in any case immigrant females and hybrid males on Bioko would be IIL-18 homozygotes, which were not found. The nearest known mainland breeding site is in southern Nigeria, approximately $230 \mathrm{~km}$ north of Bioko, on the other side of the Ndian/Cross river watershed which runs through the Oban Hills (Mafuyai et al., 1996). There is no chromosomal evidence for other cytospecies breeding on the island. Simulium damnosum s.str. and S. mengense Vajime \& Dunbar (Simuliidae) (both of which are known around the southern edges of Mount Cameroon) would be immediately obvious, and were not found on Bioko. Simulium squamosum from Cameroon east of Bioko would be easily recognized if it was rare but indigenous to Bioko because $60-70 \%$ of its males would show a sex-linked non-pairing section near the centromere of the first chromosome (Traore-Lamizana et al., 2001) and this was never found. On the other hand, rare indigenous or immigrant $S$. squamosum from the southern side of Mount Cameroon would often be chromosomally indistinguishable from the endemic Bioko form of $S$. yahense (compare tables 1 and 2), but the morphology of the adult females did not indicate the presence of $S$. squamosum.

It is probable that the taxonomic differentiation of the Bioko form of $S$. yahense results from genetical and ecological isolation caused by the position of the island (see above). There is some variation in taxonomic characters within the Bioko form, but very little evidence that any of this is subdivided geographically around the island. The sex chromosome variation (table 1 ) is too rare to show a definite pattern, but is apparently scattered around the island. Similarly, inversion 3L-I shows no discernible pattern, as illustrated by the frequency of heterozygotes clockwise around the island from Rio Ruma (considering only samples of ten or more larvae: $0.07,0.00,0.00,0.03,0.00,0.00,0.05$, $0.29,0.00,0.18,0.00$ and 0.06$)$, which show no significant clustering (one-sample runs test $P>0.05$ ). The occurrence of mixed scutellar and abdominal setae is too rare to draw a meaningful pattern from, although there might be some clustering at the southern end of the sampling distribution (R. Ruma and R. Matogi). Size of adult S. damnosum s.l. (as indicated by lengths of the thorax) is known to be strongly influenced by the environment (Cheke \& Harris, 1980), and there is again little indication of geographical structure on Bioko because nearly all of the standard deviations overlap the various sample means (table 4 ), and the four samples from the R. Apu include both the largest and smallest flies (where $n>1$ ). However, it is interesting that irrespective of the time of year all three samples from the R. Ruma are amongst the smallest (although this is not statistically significant). Flook \& Post (1997) compared RFLP profiles for pSO11 DNA (such as fig. 2) for different Bioko populations and also obtained some weak evidence for the R. Ruma population being different from those on the western side of the island, and some suggestion of differences between north and south. In summary, there is no clear evidence for geographical structuring of the Bioko form of $S$. yahense, but a number of independent characters show some possible differences between the R. Ruma and the western samples.

The high level of geographic isolation implied by the results have important implications for the potential for vector eradication from the island. There is no evidence for vector immigration, and the genetic distinctiveness of the Bioko populations actually suggests that if immigration does 
occur it must be uncommon. Therefore, if all vector breeding sites on the island can be accessed and treated with insecticide it is likely that the vector will not return for some time at least. Furthermore, and probably more importantly, if vector populations do not disappear from Bioko during the course of an eradication programme (or if they reappear thereafter), it will be possible to examine their taxonomic characteristics and to determine whether the flies are immigrants from the mainland, or whether they are the Bioko form of $S$. yahense (which must have continued breeding locally due to some sort of treatment failure). The first case would indicate an impossible obstacle to eradication, but in the second case it may be possible to locate the breeding sites and treat them to overcome the problem. Unfortunately, the taxonomic characteristics of the surviving populations will not help to locate their breeding sites, because there was very little evidence for population subdivision around the island.

\section{Acknowledgements}

Since 1989 this project has been funded mostly by the British Medical Research Council, but with important contributions from the African Programme for Onchocerciasis Control (WHO/APOC), Cooperación Española, UNDP/World Bank/WHO Special Programme for Research and Training in Tropical Diseases (TDR), the Wellcome Trust, Wageningen Agricultural University, the John Gilpin Trust, the Ulverscroft Foundation and The Natural History Museum. David Ekale, Mathias Eyong, Hans Hagen and Jan Wieringa helped collect some of the samples from Cameroon. We are most grateful to Dr Alfons Renz for access to old cytotaxonomic material from the Mount Cameroon area. Finally we would like to thank the Minister of Health of the Republic of Equatorial Guinea for collaboration and encouragement, and Dr A. Sékétéli (Director APOC) for permission to publish.

\section{References}

Baker, R.H.A., Guillet, P., Sékétéli, A., Poudiougo, P., Boakye, D. Wilson, M.D. \& Bissan, Y. (1990) Progress in controlling the reinvasion of windborne vectors into the western area of the Onchocerciasis Control Programme in West Africa. Philosophical Transactions of the Royal Society of London series B 328, 731-750.

Bingham, P.M., Levis, R. \& Rubin, G.M. (1981) Cloning of DNA sequences from the White locus of $D$. melanogaster by a novel and general method. Cell 25, 693-704.

Boakye, D.A. (1993) A pictorial guide to the chromosomal identification of members of the Simulium damnosum Theobald complex in West Africa with particular reference to the Onchocerciasis Control Programme area. Tropical Medicine and Parasitology 44, 223-244.

Boakye, D.A., Post, R.J., Mosha, F.W., Surtees, D.P. \& Baker, R.H.A. (1993) Cytotaxonomic revision of the Simulium sanctipauli subcomplex (Diptera: Simuliidae) in Guinea and the adjacent countries including descriptions of two new species. Bulletin of Entomological Research 83, 171-186.

Boatin, B.A., Hougard, J.-M., Alley, E.S., Akpoboua, L.K.B., Yaméogo, L., Dembélé, N., Sékétéli, A. \& Dadzie, K.Y. (1998) The impact of Mectizan on the transmission of onchocerciasis. Annals of Tropical Medicine and Parasitology 92, Supplement 1, S47-S60.
Capuz, R. (1953) Calanario meteorologico de los territorios Espanoles del Golfo de Guinea. Urania 233, 36-57.

Calvo Picó, J.L. (1962) Estudio sobre la oncocercosis ocular en Guinea. Revista de Sanidad e Higiene Pública 36, 157-179.

Cheke, R.A. \& Garms, R. (1983) Reinfestations of the southeastern flank of the Onchocerciasis Control Programme area by windborne vectors. Philosophical Transactions of the Royal Society of London series B 302, 471-784.

Cheke, R.A. \& Harris, J.R.W. (1980) Seasonal size variation in females of the Simulium damnosum complex in the Ivory Coast. Tropenmedizin und Parasitologie 31, 381-385.

Cheke, R.A., McCall, P.J. \& Mas, J. (1997) The vector status of the Bioko form of Simulium damnosum. Transactions of the Royal Society of Tropical Medicine and Hygiene 91, 153-154.

Davies, J.B. (1994) Sixty years of onchocerciasis control: a chronological summary with comments on eradication, reinvasion, and insecticide resistance. Annual Review of Entomology 39, 23-45.

Davies, J.B., Thomson, M.C. \& Beech-Garwood, P.A. (1988) Morphological identification of Simulium yahense and $S$. squamosum in the south of Sierra Leone confirmed by electrophoresis. Transactions of the Royal Society of Tropical Medicine and Hygiene 82, 643.

dos Santos Gracio, A.J. (1998) Blackflies (Diptera: Simuliidae) from São Tomé e Príncipe. 1. São Tomé island. Acta Parasitológica Portuguesa 2, 3-11.

Duke, B.O.L. (1990) Human onchocerciasis - an overview of the disease. Acta Leidensia 59, 9-24.

Duke, B.O.L., Lewis, D.J. \& Moore, P.J. (1966) Onchocerca-Simulium complexes I. Transmission of forest and Sudan-savanna strains of Onchocerca volvulus, from Cameroon, by Simulium damnosum from various West African bioclimatic zones. Annals of Tropical Medicine and Parasitology 60, 318-336.

Fiasorgbor, G.K., Sowah, S.A., Boakye, D.A. \& Zerbo, G. (1992) Distribution of Simulium yahense after larviciding activities in the southern extension of the Onchocerciasis Control Programme. Tropical Medicine and Parasitology 43, 72-73.

Flook, P.K. (1992) Studies of genomic variation in Simulium damnosum s.l. (Diptera: Simuliidae) with special reference to the Bioko form of the S. squamosum subcomplex. PhD thesis, University of Liverpool.

Flook, P.K. \& Post, R.J. (1997) Molecular population studies of Simulium damnosum s.l. (Diptera: Simuliidae) using a novel interspersed repetitive DNA marker. Heredity 79, 531-540.

Flook, P.K., Wilson, M.D. \& Post, R.J. (1992) The use of repetitive DNA probes in the analysis of natural populations of insects and parasites. pp. 484-486 in Berry, R.J., Crawford, T.J. \& Hewitt, G.M. (Eds) Genes in ecology. Oxford, Blackwell Scientific Publications.

Fryauff, D. \& Trpis, M. (1986) Identification of larval and adult Simulium yahense and Simulium sanctipauli based on species-specific enzyme markers and their distribution in different breeding habitats in central Liberia. American Journal of Tropical Medicine and Hygiene 35, 1218-1230.

Garms, R. (1978) Use of morphological characters in the study of Simulium damnosum s.l. populations in west Africa. Tropenmedizin und Parasitologie 29, 483-491.

Garms, R. \& Cheke, R.A. (1985) Infections with Onchocerca volvulus in different members of the Simulium damnosum complex in Togo and Benin. Zeitschrift für Angewandte Zoologie 72, 479-495. 
Garms, R. \& Zillman, U. (1984) Morphological identification of Simulium sanctipauli and $S$. yahense in Liberia and comparison of results with those of enzyme electrophoresis. Tropenmedizin und Parasitologie 35, 217-220.

Garms, R., Walsh, J.F. \& Davies, J.B. (1979) Studies on the reinvasion of the Onchocerciasis Control Programme in the Volta River basin by Simulium damnosum s.l. with emphasis on the south-western areas. Tropenmedizin und Parasitologie 30, 345-362.

Garms, R., Cheke, R.A., Vajime, C.G. \& Sowah, S.A. (1982) The occurrence and movements of different members of the Simulium damnosum complex in Togo and Benin. Zeitschrift für Angewandte Zoologie 69, 219-236.

Garms, R., Cheke, R.A., Fiasorgbor, G.K. \& Walsh, J.F. (1989) Seasonal extension of the breeding range of Simulium sanctipauli from forest into savanna in eastern Ghana and Togo. Zeitschrift für Angewandte Zoologie 76, 457-467.

Jones, P.J. (1994) Biodiversity in the Gulf of Guinea: an overview. Biodiversity and Conservation 3, 772-784.

Kafatos, F.C., Jones, C.W. \& Efstratiadis, A. (1979) Determination of nucleic acid sequence homologies and relative concentrations by a dot blot hybridization procedure. Nucleic Acids Research 7, 1543-1552.

Kläger, S., Whitworth, J.A.G., Post, R.J., Chavasse, D.C. \& Downham, M.D. (1993) How long do the effects of ivermectin on adult Onchocerca volvulus persist? Tropical Medicine and Parasitology 44, 305-310.

Kurtak, D.C., Raybould, J.N. \& Vajime, C.G. (1981) Wing tuft colours in the progeny of single individuals of Simulium squamosum (Enderlein). Transactions of the Royal Society of Tropical Medicine and Hygiene 75, 126.

Lewis, D.J. \& Duke, B.O.L. (1966) Onchocerca-Simulium complexes II. Variation in West African female Simulium damnosum. Annals of Tropical Medicine and Parasitology 60, 337-346.

Mafuyai, H.B., Post, R.J., Vajime, C.G. \& Molyneux, D.H. (1996) Cytotaxonomic identifications of the Simulium damnosum complex (Diptera: Simuliidae) from Nigeria. Tropical Medicine and International Health 1, 779-785.

Mas, J., Sima, V. \& Yumbe, A. (1990) Prevalence and geographical distribution of onchocerciasis on the island of Bioko (Equatorial Guinea). Acta Leidensia 59, 458.

Mas, J. Yumbe, A., Sole, N., Capote, R. \& Cremades, T. (1995) Prevalence, geographical distribution and clinical manifestations of onchocerciasis on the island of Bioko (Equatorial Guinea). Tropical Medicine and Parasitology 46, 13-18.

McCall, P.J., Wilson, M.D., Dueben, B.D., de Clare Bronsvoort, B.M. \& Heath, R.R. (1997) Similarity in oviposition aggregation pheromone composition within the Simulium damnosum (Diptera: Simuliidae) species complex. Bulletin of Entomological Research 87, 609-616.

McCall, P.J., Cheke, R.A., Wilson, M.D., Post, R.J., Flook, P.K., Mank, R., Sima, A. \& Mas, J. (1998) Distribution of the Simulium damnosum complex on Bioko island, Equatorial Guinea, and the potential for onchocerciasis elimination by vector eradication. Medical and Veterinary Entomology 12, 267-275.

McMahon, J.P. (1967) A review of the control of Simulium vectors of onchocerciasis. Bulletin of the World Health Organization 37, 415-430.

Meredith, S.E.O. \& Townson, H. (1981) Enzymes for species identification in the Simulium damnosum complex from West Africa. Tropenmedizin und Parasitologie 32, 123-129.
Meredith, S.E.O., Cheke, R.A. \& Garms, R. (1983) Variation and distribution of forms of Simulium soubrense and $S$. sanctipauli in West Africa. Annals of Tropical Medicine and Parasitology 77, 627-640.

Nosti, J. (1942) Climatologia de los territorios Españoles del Golfo de Guinea. Instituto de Estudios Africanos, Consejo Superior de Investigaciónes Cientificas, Madrid.

Nosti, J. (1947) Notas Geograficas, Fisias y Economicas sobre los territorios Españoles del Golfo de Guinea. Instituto de Estudios Africanos, Consejo Superior de Investigaciónes Cientificas, Madrid.

Post, R.J. (1986) Cytotaxonomy of Simulium sanctipauli and Simulium soubrense (Diptera: Simuliidae). Genetica 69, 191-207.

Post, R.J. \& Boakye, D.A. (1992) Vector taxonomy and the control of human onchocerciasis in West Africa. Proceedings of the section Experimental and Applied Entomology of the Netherlands Entomological Society (N.E.V.) 3, 105-109.

Post, R.J. \& Flook, P.K. (1992) DNA probes for the identification of members of the Simlium damnosum complex (Diptera: Simuliidae). Medical and Veterinary Entomology 6, 379-384.

Post, R.J., Flook, P.K. \& Wilson, M.D. (1992) DNA analysis in relation to insect taxonomy, evolution and identification. pp. 21-34 in Crampton, J.M. \& Eggleston, P. (Eds) Insect molecular science. London, Royal Entomological Society.

Post, R.J., Flook, P.K. \& Millest, A.L. (1993) Methods for the preservation of insects for DNA studies. Biochemical Systematics and Ecology 21, 85-92.

Post, R.J., Mas, J., Millest, A.L. \& Flook, P.K. (1995) Is the Bioko form of the Simulium damnosum complex (Diptera: Simuliidae) geographically isolated? Proceedings of the section Experimental and Applied Entomology of the Netherlands Entomological Society (N.E.V.) Amsterdam 6, 193-194.

Remme, J.H.F. (1995) The African Programme for Onchocerciasis Control: preparing to launch. Parasitology Today 11, 403-406.

Sambrook, J., Fritsch, E.F. \& Maniatis, T. (1989) Molecular cloning: a laboratory manual, 2nd edn. Cold Spring Harbor, New York, Cold Spring Harbor Laboratory Press.

Southern, E.M. (1975) Detection of specific sequences among DNA fragments seperated by gel electrophoresis. Journal of Molecular Biology 98, 503-517.

Teran, M. de (1962) Sintesis geografica de Fernando Poo. Madrid, Instituto de Estudios Africanos, Consejo Superior de Investigaciones Cientificas.

Thomson, M.C., Davies, J.B. \& Wilson, M.D. (1989) A portable allozyme electrophoresis kit used to identify members of the Simulium damnosum Theobald complex (Diptera: Simuliidae) in the field. Bulletin of Entomological Research 79, 685-691.

Traore-Lamizana, M. \& Lemasson, J.J. (1987) Participation à une étude de faisabilité de campagne de lutte contre l'onchocercose dans la région du bassin du Logone. Répartition des espèces du complexe Simulium damnosum dans la zone camarounaise du projet. Cahiers ORSTOM, série Entomologie Médicale et Parasitologie 25, 171-186.

Traore-Lamizana, M., Somiari, S., Mafuyai, H.B., Vajime, C.G. \& Post R.J. (2001) Sex chromosome variation and cytotaxonomy of the onchocerciasis vector Simulium squamosum (Diptera: Simuliidae) in Cameroon and Nigeria. Medical and Veterinary Entomology 15, 219-223.

Vajime, C.G. \& Dunbar, R.W. (1975) Chromosomal identification of eight species of the subgenus Edwardsellum near and including Simulium (Edwardsellum) damnosum 
Theobald (Diptera: Simuliidae). Tropenmedizin und Parasitologie 26, 111-138.

Walsh, J.F. (1990a) Discussion (on the elimination of the Djodji form of Simulium sanctipauli). Philosophical Transactions of the Royal Society of London series B 328, 727-728.

Walsh, J.F. (1990b) Review of vector control prior to the OCP. Acta Leidensia 59, 61-78.

WHO (1987) WHO expert committee on onchocerciasis - third report. WHO technical report series 752, World Health Organization, Geneva.

Wilson, M.D., Post, R.J. \& Gomulski, L.M. (1993) Multivariate morphotaxonomy in the identification of adult female Simulium damnosum Theobald complex (Diptera:
Simuliidae) in the Onchocerciasis Control Programme area of West Africa. Annals of Tropical Medecine and Parasitology 87, 65-82.

Wilson, M.D., Mafuyai, H.B. \& Post, R.J. (1994) Morphological identification of sibling species of the Simulium damnosum (Diptera: Simuliidae) complex from Nigeria, Cameroun and Bioko. Proceedings of the section Experimental and Applied Entomology of the Netherlands Entomological Society (N.E.V.) 5, 181-185.

(Accepted 16 December 2002) (C) CAB International, 2003 


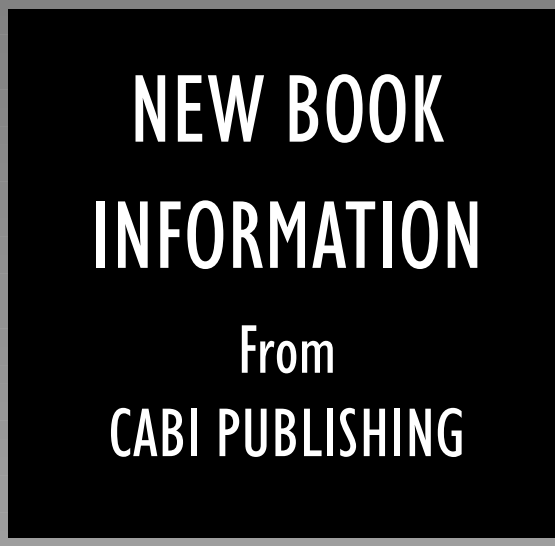

\section{Readership}

Agricultural and environmental economics, environmental sciences research workers, advanced students, lecturers and policy makers.

\section{Description}

This book describes the environmental problems associated with agriculture, particularly the use of pesticides and chemical fertilizers and the disposal of animal waste. These have become major policy issues in many countries, with the main polluting effect being on water quality. As with other types of pollution, significant reductions in agriculture's contribution to water pollution requires the application of either enforceable regulatory approaches or changes in the economic environment, so that farmers adopt environmentally-friendly production practices. Providing a review and guide to the policy options and their economic administrative and political merits, the reader can develop an understanding of these options and their merits in the emerging policy context. The principal focus is on the developed world, particularly North America and Europe. The book is aimed at advanced students, researchers and professionals in agricultural economics and policy, and environmental and pollution sciences.

\section{To view full contents or to order online please visit www.cabi-publishing.org/bookshop}

Postage \& Packing: For pre-paid orders in the UK, please add $£ 2.75$ for the Ist book and 60p for each additional book ordered (up to max. of 10 ). For prepaid orders elsewhere, please add $£ 4.00$ for the Ist book and $£ \mathrm{I} .00$ for each additional book. For orders not pre-paid, postage and packing will be charged according to the weight of the book.
CABI Publishing, CAB International Wallingford,

Oxon OXIO 8DE, UK

Tel: $+44(0)$ I 49 I 832 I I I

Fax: $+44(0)|49| 829292$

Email: orders@cabi.org
CABI Publishing North America

44 Brattle Street, 4th Floor Cambridge, MA 02138, USA Tel: 00I 6I 73954056

Fax: 00I 6I 73546875

Email: cabi-nao@cabi.org 